\title{
Patents, commercialization and the $C$ anadian stem cell research community
}

\section{Timothy C aulfield ${ }^{1 \dagger}$, U baka 0 gbogu2, Charles M urdoch ${ }^{3}$ \& Edna Einsiedel ${ }^{4}$}

${ }^{\dagger}$ Author for correspondence ${ }^{1} \mathrm{H}$ ealth Law Institute, Faculty of L aw, U niversity of Alberta, Edmonton, Alberta, Canada

Tel.:+1 7804928358 ;

Fax: +1 780492 9575;

E-mail: tcaulfld@law. ualberta.ca

${ }^{2} \mathrm{H}$ ealth Law Institute, Faculty of Law, U niversity of Alberta, Edmonton, Alberta, Canada

Tel.:+1 7804929055 ;

Fax: +1 780492 9575

E-mail: uogbogu@law.

ualberta.ca

${ }^{3} \mathrm{H}$ ealth Law Institute,

Faculty of Law, U niversity of Alberta, Edmonton, Alberta,

Canada

Tel.:+1 780492 8343;

Fax: +1 780492 9575;

E-mail: charlesm@

ualberta.ca

${ }^{4}$ Faculty of Communication

$\&$ Culture, University of

Calgary, Calgary, Alberta,

Canada

Tel.:+1 403220 3924;

Fax: +1 403282 6716;

E-mail: einsiede@ucalgary.ca

Keywords: academic integrity, commercialization, conflicts of interest, data withholding, licensing, patents, publication delays, research, social benefit, stem cell

fitured edicine 1 isg

\begin{abstract}
Aims: There has been a great deal of discussion in relevant literature on the adverse impact of commercialization agendas and the patenting regime on research in emerging fields.

We sought to assess the perceived impact of these factors on the stem cell research community in Canada. Materials \& methods: We surveyed 283 researchers from

Canada's Stem Cell Network using a survey instrument informed by relevant literature and systematic consultations with Canadian and international regulators, stem cell researchers and research ethics experts designed to identify pressing ethical, legal and social issues relevant to stem cell research. A total of 108 researchers responded to the survey.

Results $\&$ conclusions: Results indicate that although many researchers believe that patents may have adverse effects on research, very few have encountered any such effects in practice. The researchers admitted to withholding data to protect patenting opportunities, while also maintaining that patents did not contribute to publication delays. The pressure to commercialize their research was largely held to be reasonable by researchers.
\end{abstract}

Lately there has been increasing concern in academic literature about the growing ties between industry and the academic research community [1-6]. For example, there is emerging evidence that these relationships can increase information withholding among researchers [7-10], skew the direction of research results toward findings supportive of industry sponsors $[8,9,11]$, alter the tone of popular representations of research [12] and, perhaps most importantly, erode public trust in the research and researcher $[13,14]$.

At the same time, there continues to be national and international debate regarding the appropriateness of biotechnology patents, particularly in the areas of genetics and stem cells $[15-19,101]$. While the evidence remains less than robust, some commentators have speculated that patents hurt the research environment by increasing secrecy and costs [7,10,20-22].

Several commentators have also speculated about the adverse implications of commercialization and patents in the context of stem cell research [23-25]. H owever, there are, in fact, few empirical studies exploring the impact of commercialization and patenting on key players such as stem cell researchers and the public. A recent Australian study explored public perception of a privatized stem cell research environment, noting a decline in trust, but did not examine researcher perceptions or the actual impact on the research environment [14]. Indeed, much of the public debate surrounding stem cell research has focused on issues associated with the moral status of the embryo. But as this research moves forward, patenting and commercialization issues seem likely to move to the fore $[16,18]$. Indeed, many publicly funded stem cell programs, such as those in California, are explicitly justified by reference to potential commercial development and economic growth. In Canada, facilitating commercialization and knowledge translation are part of the mandate of the Stem Cell N etwork (SCN), C anada's largest consortium of stem cell researchers [23]. Given the increasing relevance of patents and commercialization activities to the research environment, it seems apt to investigate their impact on research and researchers.

To this end, we conducted a survey of members of the Canadian stem cell community with two objectives in mind: first, to obtain information regarding current trends in intellectual property protection, exploitation and transfer and the practical challenges associated with protecting and using biotechnology inventions; and second, to determine the researchers' general impressions about stem cell patents and research commercialization. Because the Canadian stem cell research community is relatively small, and most of $C$ anada's stem cell researchers have some relationship with the SCN, the 2006 AGM of the N etwork provided an ideal opportunity to administer the survey.

Methods

Survey instrument design

The design of the survey instrument was informed by systematic consultations with Canadian and international regulators, stem cell 
researchers and research ethics experts. The purpose of the consultations, which also included an expert workshop [26,27], was to identify pressing ethical, legal and social issues relevant to stem cell research in Canada. A comprehensive analysis of relevant literature on the impacts of commercialization and patenting on research was also undertaken $[13,28]$, leading to the production of review articles and commentaries [23,29]. We also reviewed published empirical studies on similar topics for guidance on framing the questions.

The anonymized survey instrument consisted of 41 questions on current trends in intellectual property protection, exploitation and transfer, researchers' views on the value of patents and the practical challenges associated with protecting and using biotechnology inventions, and the nature and impact of commercialization activities on research (see supplement $A$ ).

Sample selection \& survey administration The sample group consisted of 309 registered delegates, including stem cell scientists, ethics, law and public policy scholars, trainees/students and guests in attendance at the SCN AGM in N ovember 2006. The SC $N$ is a federally funded, nonprofit research corporation comprising scientists, clinicians, engineers, ethicists and lawyers involved in stem cell research. The rationale for choosing this sample population is that the $\mathrm{SCN}$ is the only network of researchers involved with stem cell research in Canada. Furthermore, the $\mathrm{SCN}$ is funded by the $\mathrm{C}$ anadian federal government's N etworks of Centres of Excellence program [102] to be the focal point for stem cell research activities in Canada and is periodically assessed, by external peer review, for its ability to bring together most (if not all) the leading stem cell researchers in the country. For example, all of the researchers involved in the derivation of embryonic stem cell lines in Canada are SCN members [30]. A survey of the SCN provides a unique opportunity to capture the views of a significant portion of the nation's stem cell research community.

To ensure that only persons in the sample group received the survey, the instrument was placed in stamped self-addressed envelopes and distributed by hand to the group at the registration desk. A total of 283 surveys were handed out. Participants were asked to complete and return the surveys by mail, to members of our research team, or by placing in various drop-off boxes at the meeting venue.
At the time of the survey, the $\mathrm{N}$ etwork comprises 72 principal investigators (PIs) and 367 trainees. Among the PIs, seven are involved in the N etwork's law, ethics and public policy work and three are honorary members. The remaining $62 \mathrm{PIs}$ are scientific researchers, but only 47 of this category of PIs were active in the $N$ etwork (i.e., participating in research activities) at the time of the survey. The trainee group consists of 33 research associates, 64 technicians, 87 postdoctoral fellows, 28 undergraduate students and 155 graduate students.

Network members registered for and in attendance at the AGM included $45 \mathrm{PIs}$ and 204 trainees. The PI population in attendance included 31 active scientific researchers, three law, ethics and public policy researchers and 11 nonactive scientific researchers. The three PIs involved in law, ethics and public policy work were excluded from the survey, as this group was involved in this research. The final sample population therefore consisted of 204 trainees and 42 scientific PIs who were either active and participating in Network research, or were currently nonactive but may have participated in research activities in the past or are likely to participate in the future. This final number of PIs constitutes approximately $68 \%$ of the total number of scientific researchers in the N etwork at the time of the survey, and includes approximately $66 \%$ of scientific researchers currently active in the $\mathrm{N}$ etwork. W hile the sample size is relatively modest, we believe it represents a majority of the lead researchers in the Canadian stem cell research community.

Response rate $\&$ method of analysis

A total of 108 surveys (38\%) were completed and returned to us. A total of 27 responses were from PIs (64\% of PIs that participated in the survey and approximately $44 \%$ of the $N$ etwork's science PIs). A total of 81 responses were received from trainees (approximately $40 \%$ of participating trainees). Three of the PIs who responded specifically noted they were not members of the N etwork, and two of the three identified themselves as coinvestigator and collaborator on N etwork-funded projects respectively. Since coinvestigators and collaborators on N etwork-funded projects are likely to possess knowledge of the matters covered in the survey, the decision was made to include in our analysis the responses from the two nonmember PIs who self-identified as coinvestigator and/or 
collaborator. We also included the nonmember $\mathrm{PI}$, as a nonactive member might self-identify as a nonmember.

The 81 trainees that responded to the survey consist of 37 graduate students, three undergraduate students, 13 research associates, 24 postdoctoral fellows and four technicians. This group of respondents constitutes approximately $40 \%$ of trainees in attendance at the AGM. In sum, $27 \mathrm{PIs}$ and 81 trainees constitute the final number of respondents used in our analysis of the survey results.

The surveys were aggregated and analyzed using SPSS statistical analysis software. O penended responses were ignored, as there were too few of these to be statistically significant.

\section{Results}

The survey results were categorized and analyzed under two response groups: network PIs and trainees. The main reason for this approach is that we wanted to isolate and determine the impressions of PIs, as they were the subset of the entire sample group most likely to be involved in research commercialization activities. Although the actual percentages are slightly disproportionate between the two groups surveyed, the trend of responses obtained from trainees generally corresponds to that of the PIs (see Appendix). As such, we only highlight interesting similarities and differences between both sets of responses.

\section{General}

Respondents were asked to identify all applicable categories that describe the nature of their research from a list of options. A total of $19 \mathrm{PIs}$ indicated involvement in basic research, 14 in applied research, three in clinical research and 11 in translational research. A majority of the trainees conduct basic research $(\sim 78 \%)$ in the area of 'stem cell applications and cellular therapy' ( 72\%).

$M$ ost respondent $\mathrm{PIs}$ conduct their research in a university laboratory (17 PIs) or in academic medical centers (13 PIs). O nly one researcher works in a government laboratory and none of the PIs are primarily affiliated with corporations. Among trainees, the venue of research was similar to that of the PI group, with research most frequently conducted in a university laboratory, followed by academic medical centers. $N$ one of the trainees were affiliated with government laboratories, and only three worked in profit or nonprofit corporations.
Almost all the PIs and trainees surveyed agreed that the most important factors motivating their research careers were high quality of research, academic integrity and the ability to obtain research funding. Publication record and peer recognition were rated very high on the scale of importance, while factors such as monetary gain, job security or tenure, and the development of inventions or a patenting record were rated moderately important or not important at all.

Patents

We solicited responses from the PIs surveyed on the importance of various kinds of benefit derived from holding research patents. Responses were rated on a scale of 1-5, with 5 being 'very important'. Almost all of the PIs who responded to the relevant questions (26 of 27) identified the development of beneficial products and services for society as very important or important. Approximately threequarters of the PIs (19) considered the role of patents in facilitating research translation to be important or very important, while over half (14) said patents were important or very important in facilitating private sector investment. A total of 12 PIs felt that way regarding the role of patents in relation to the receipt of research grants. 0 ther benefits, such as monetary gain, career advancement and building a patent portfolio, were rated as moderately important to not important at all, with few researchers (less than a third) rating these benefits as important or very important.

The PIs seemed to have a strong awareness of patent controversies. M ore than half of the PIs stated they were aware of controversies surrounding human gene patents, stem cell patents, patents over plant and animal varieties, and patents on genetically modified organisms.

The researchers' views on the overall impact of patents on the research environment were evenly split. A total of 13 out of $25 \mathrm{PIs}$ were of the view that patents had a positive impact on the research environment, while 12 stated that they had a negative impact (two did not respond). Of those who indicated that patents had a negative impact, almost all agree or strongly agree with the potential negative effects of patenting listed in the questionnaire: that patents are often overly broad in scope, can limit the ability of researchers to carry out important research, increase secrecy among researchers, unduly increase the cost of doing research, 
reduce researchers' ability to use patented technologies, increase dependence on industry and decrease public trust in science. A quarter of the $\mathrm{PIs}$ in this category agreed or strongly agreed that patents skew academic research towards commercial goals at the expense of exploring research avenues traditionally undertaken.

A majority (8-11) of the 13 PIs who agreed that patents have a "positive impact on research" agree or strongly agree that patents facilitate the development of technologies for use by society, increase the chances of obtaining research grants and awards, and provide researchers with the ability to exchange their inventions for value, recoup research and development costs and fund future research. Fewer numbers of researchers in this category (five to seven) agree or strongly agree with claims that publication of patents in the public domain ('public domain' refers to openly accessible nature of patent databases and is not intended to convey the meaning that the information/invention disclosed is freely available for use without the patent-holder's permission. The researchers surveyed are familiar with the latter understanding, and are not likely to be misled by the survey question [see supplement A]) facilitates information sharing between researchers, and provide researchers with the ability to identify and use the inventions of others. Given that the information disclosure function of patents is often viewed as balancing society's granting of exclusive rights [31,32], the latter finding suggests a lack of enthusiasm for a conventional benefit associated with patents, and warrants future investigation.

D espite the concerns expressed by the 12 PIs who view patents negatively, it would appear that most of the PIs surveyed have not experienced the expressed negative effects of patenting. Only a small number of PIs (five) stated that they had refused to license patented technology to someone who approached them directly with a request for a license. Almost half of the PIs (12) specifically stated that they had never refused such requests, while the remaining PIs either did not respond, hold patents or did not know. Although 14 PIs had accessed patented technology to perform their research (including eight for nonexclusive use and one for exclusive use: others did not respond or did not know), only two PIs had been refused licenses to patented technologies they needed for their research. Both PIs stated that following the refusal, they continued their research without a license by utilizing alternative methods and approaches to work around the patented technology. H owever, a significant number of PIs (18) admitted having withheld information about their research in order to protect potential patents.

The most common basis for refusal by the PIs to license their patents to others include competition and potential licensees' unwillingness to pay sufficient royalty fees. 0 ther reasons given include lack of time to deal with request and recognition of the Technology Transfer Office's expertise in negotiating better deals. It is important to note, however, that since only a few PIs had refused to license their patents to others, the data on basis for refusal is hardly significant. Indeed, not more than two PIs responded in each case.

The researchers' views on the practical effects of patenting on knowledge dissemination differed with respect to whether the research information was verbal or unpublished research, or actual publications. A total of $63 \%$ of the PIs (17 PIs) did not agree that the potential to patent caused a delay in publishing their research results, while (as stated previously) 66\% (18 PIs) stated that they had withheld information about their research in order to protect potential patents.

A higher proportion of trainees than PIs view patents as having a positive impact on the research environment. Specifically, 55\% of trainees that responded felt that patents had a positive impact on the research environment, while $45 \%$ felt they had a negative impact.

Involvement in

commercialization activities

M ost of the PIs surveyed were involved in commercialization activities. A total of 22 PIs have been named as inventor on at least one granted patent or pending patent applications (which may or may not relate to stem cells). Ten of these individuals hold shares in a company that licensed technology they had developed. PIs in this group had negotiated license agreements to permit others to use patented technology that they had created, including ten agreements with private companies, five with universities, four with other researchers, four with academic medical centers and one with a public company. A total of 11 of the licenses granted by the PIs allowed exclusive use by other researchers, while six allowed only nonexclusive uses. PIs that did not respond either did not know the details of their license agreements or did not answer the survey question. 
Among trainees, only 15 have been named as inventor on granted patents or pending patent applications, and each held between one and five such patents. Of this group, only three trainees held shares in a company that licensed technology they had developed. Four trainees had negotiated license agreements to permit others to use patented technology that they had created, and 21 stated that they had requested access to patented technology held by other parties. However, none of the trainees had ever refused to license patented technology to others, and only two trainees had been refused licenses to patented technologies needed for their research (and they worked around the refusal).

The data show a high level of material and information sharing among PIs. A total of $93 \%$ routinely share research materials with colleagues at other institutions or within private firms. It is unclear how much material or information is withheld by the researchers, especially since, as reported previously, $66 \%$ of PIs admitted to having withheld information in order to protect potential patents. M aterial transfer agreements (M TAs) were the popular means of exchanging technologies: almost all respondents had been asked to sign M TAs in exchange for receipt of research materials held by someone else, while two-thirds (67\%) had asked another party to do so. Interestingly, about six in ten PIs had been denied a request for research materials, mostly owing to competition among researchers and lack of time to deal with such requests. O nly four PIs have refused to provide research materials to a requesting party, again mostly owing to competition. 0 ne PI stated that the company he worked with restricted distribution of their research material, as they "were not sure materials would not be used for other reasons than stated." The PI also noted that "the requesting lab was a [senior] investigator with a reputation for screwing over other labs."

$M$ aterial and information sharing was also a common practice among trainees. Approximately $77 \%$ of trainees stated that they routinely share research materials with colleagues at other institutions or within private firms. A total of $52 \%$ had been asked to sign MTAs prior to receipt of research materials, while $26 \%$ have asked others to do so. Unlike the $\mathrm{PI}$ group, a smaller percentage of trainees $(21 \%)$ had been denied a request for research materials, mostly owing to competition among researchers. H owever, only two trainees had themselves refused to provide research materials to a requesting party, again owing to competitive reasons.

Contrary to speculation in relevant literature that the pressure to commercialize research may have a negative impact on researchers and research activities [23,33], $48 \%$ of PIs (13 PIs) found the overall impact of the SCN 's commercialization activities on research efforts to be neutral, while $41 \%$ (11 PIs) believed it to be positive and $7 \%$ (two PIs) found it to be negative. Similarly, $44 \%$ (12 PIs) found the impact of the Network's commercialization activities on the teaching and training environment to be neutral, while 33\% (ninePIs) believed it to be positive and 19\% (five PIs) found it to be negative.

We also solicited responses on sources of pressure to commercialize research. Responses were rated on a scale of 1-5 with 5 being 'extreme' and 1 'not at all'. In the extreme category, the most pressure came from industrial partners, followed by the SCN and the researchers' home universities. H owever, it suffices to note that a higher proportion of responses with respect to the various sources were in the moderate to not at all categories.

A total of $23 \mathrm{PIs}$ reported that the pressure to commercialize their research was reasonable (two felt it was unreasonable, one did not respond). H owever, 13 PIs noted that based on their current level of understanding of the commercialization process, they do not know enough about patenting and commercialization to make wise decisions about the commercial development and exploitation of their research (12 knew enough to make decisions, two did not respond).

The data obtained from the trainees on impacts of commercialization pressure on research and training activities, sources of pressure to commercialize, and understanding of the commercialization process are very similar to the PI data. The actual measurements are provided in Table A1 \& Figures A1-A9.

\section{Discussion}

This survey provides a unique picture of the attitudes of Canadian stem cell researchers on a variety of commercialization issues. This is a community that views itself as relatively aware of patenting controversies. To some degree, then, it is not surprising that about half viewed patents in a negative light. Those who viewed patents negatively, whether PI or trainee, agreed with the 
usual list of social concerns outlined in the literature: in sum, that patents hurt the research environment by increasing secrecy and making it more difficult get the materials needed to conduct research. However, this concern regarding patents did not necessarily correspond to the actual reported experience that PIs and trainees had with patents. Indeed, only two PIs reported that they had been refused licences on patented material. This finding fits the data from other studies, such as work by Walsh and colleagues [103] and the recent international analysis by the American Association for the Advancement of Science [34]. This latter study found that "IP-protected technologies remain relatively accessible to the broad scientific community." In other words, there was little evidence that patents were actually interfering with the research process.

A possible reason for the negative perception of patents might befound in recent high-profilecontroversies involving biotechnology patents (such as the $\mathrm{H}$ arvard $\mathrm{O}$ ncomouse and $\mathrm{M}$ yriad Genetics BCRA1/2 cases), many of which have received immense mention in the popular press and academic literature [13,16,28,35-41,104]. Informationwithholding practices associated with potential patenting opportunities, which (as our data confirm) appear to be pervasive among researchers, may also account for the negative view of patents.

M oreover, when explicitly asked, a majority of the PIs surveyed agreed that patents benefit society by facilitating knowledge translation, investment and the production of useful technologies and products. This is not to say that Canadian stem cell researchers always have easy access to needed research materials. A total of $59 \%$ had been denied a request for research materials. H owever, there was a perception that academic competitiveness (not patents per se) was the principal reason for the denial (although academic competitiveness could include concerns about the prospects of future patents for improvements on or materials derived from licensed technology). Indeed, the four PIs who admitted refusing research materials to a requesting party said they did so for competitive reasons. Again, this result corresponds well with other data. For example, H ong and Walsh conclude in a recent study that "scientific competition is a significant predictor of secrecy" as well as "an important predictor of withholding of research materials and unpublished data" [10].

Furthermore, it is interesting to note that the few researchers who were refused access to research materials proceeded to work or invent around the refusal. Given that the effect of patents on sharing and collaborative practices is a key concern to this community, this potential impact on innovation is worth exploring.

It does appear from the data that patents have a less than desirable effect on knowledge dissemination practices. A majority of researchers reported withholding information about their research in order to protect potential patenting opportunities. This is not an unusual finding, as past studies have documented this trend among biomedical researchers, and even among trainees $[7,9,42]$. Interestingly, contrary to previous studies associating patent holdings with publication delays [9,21], a similar majority of researchers did not agree that the potential to patent caused them to delay publishing their research. With these results, it would appear that the researchers are making a distinction between verbal or unpublished research withholding, and publication withholding. The results may also reflect a perception in this community that patenting is part of the overall research publication process and as such, any associated delays are integral to the process and expected. M ore research on this point seems warranted.

It is worthy of note that, despite evidence and literature noting the potential adverse impact of commercialization pressure, only a few of the PIs or trainees thought the $\mathrm{SCN}$ commercialization agenda was having a negative impact on the research environment. Indeed, a significant number thought it was having a positive impact and almost all said the commercialization pressure was reasonable. Given the ongoing debates about the increasing pressure to commercialize university research, the literature on the potential adverse effects of commercialization (some written by authors of this paper, for example, $[23,29])$ and about the SCN commercialization agenda specifically $[23,25]$, we expected more scepticism from this community, particularly the trainees. Of course, there are a number of possible explanations for this finding, including the possibility that commercialization pressure is, in fact, having little impact on the research environment (speculation that is supported by the fact that $48 \%$ say the impact on the research environment is neutral) or that the PIs and trainees believe in the value of commercialization and, as such, view any adverse impact as a reasonable trade-off. Another explanation, at least for the PIs, is that this group of researchers helped to build the SCN with the full knowledge that the relevant federal funding agency 
(the $N$ etworks of $C$ entres of Excellence program) has a commercial agenda. As such, they had expected and accepted the commercialization agenda prior to getting involved and are, therefore, predisposed to view the commercialization agenda in a relatively positive light.

of course, there are a number of limitations to a survey of this nature. First, the survey is merely an exploration of perceptions and reveals only scant information about the actual impact of patents and commercialization pressure. As noted previously, there is a reasonable amount of evidence that commercialization and involvement with industry has an impact on the research environment and on the production and dissemination of knowledge. $\mathrm{H}$ owever, this survey provides some preliminary data to suggest that this community does not have major concerns about commercialization in this context. (Some caveats suffice here. Most of the researchers also reported a general lack of knowledge about commercialization in the context of their research. This could account for the lack of concern about commercialization. In addition, this survey does not account for researchers' perceptions about specific concerns associated with commercialization in relevant literature, for example, conflicts of interest and impact on public trust.)

Second, it is possible that the results reported may be biased by any number of idiosyncratic factors (e.g., some responses may be motivated by the need to preserve a positive self or professional image). H owever, we are confident that such biases are significantly limited by the anonymization of the survey instrument.

Lastly, although it is a relatively in-depth survey, the sample size is not large and, as such, one needs to be cautious about broad generalization. W hile the survey analysis does not reveal reasons for the low response rate, we were surprised at the level of response as many of the N etwork PIs have notoriously busy schedules. Indeed, this might suggest that the survey focuses on a timely issue affecting their research. In addition, we speculate that the PIs who responded are likely to be those currently active in the N etwork, and as such, we may have captured the key population for the purpose of this survey. That said, because the $\mathrm{SCN}$ is one of $\mathrm{C}$ anada's major stem cell research funding entities and the only national network on point, we believe that we did manage to capture an important and influential segment of Canada's stem cell research community.

\section{Conclusion}

In summary, this survey largely supports recent studies that have found minimal evidence of problems associated with patenting and commercialization of research. A significant portion of the community expressed concern about the impact of patents, but few reported any specific adverse effects. Almost all agreed with the stated benefits of patents and few thought the commercialization agenda was having a negative impact on research. But this is a survey of perceptions only. M ore research is required on the actual impact of patents and commercialization on publication practices and the research environment generally.

D espite our findings, it is important not to dismiss concerns associated with patents and research commercialization as unwarranted or misplaced. Stem cell research remains relatively new science, and it is quite possible that the various mechanisms used to stimulate innovation in this developing area cushion the perceived adverse impact of patents or commercialization.

\section{Future perspective}

Current (traditional) methodologies utilized for measuring the impacts and social benefits of health research and innovation policies might be improved (or complemented) by the development of case study approaches that allow for a more objective and nuanced analysis, such as by tracking research outputs, knowledge flows and diffusion of specific technologies, rather than the effect of the policies on individual actors.

\section{Acknowledgements}

The authors would like to thank $L$ Sheremeta, $K$ Fernando, R HydeLay, N H awkins, D Lyall, SChargé, L Barron, $T M$ offat and $L$ Freeman for their invaluable research and administrative assistance. They would also like to thank T Bubela and the peer reviewers for their helpful insights, and our $\mathrm{H}$ ealth Law Institute research team for ongoing research support.

Financial \& competing interests disclosure

The authors would like to thank the Canadian Stem Cell $\mathrm{N}$ etwork and the Alberta $\mathrm{H}$ eritage Foundation for $\mathrm{M}$ edical Research for funding support. The authors have no other relevant affiliations or financial involvement with any organization or entity with a financial interest in or financial conflict with the subject matter or materials discussed in the manuscript apart from those disclosed.

$\mathrm{No}$ writing assistance was utilized in the production of this manuscript. 


\section{Executive summary}

\section{Assessing the impact of patents \& commercialization on stem cell researchers}

- While patents and research commercialization have been linked to a number of adverse impacts on research, there is little or no evidence of such impacts on emerging health biotechnologies such as stem cell research.

- This study sought to examine the perceived impact of patents and commercialization on Canadian stem cell researchers. We were able to survey a (justifiably) significant segment of this population.

\section{With patents, perception is no match for reality}

- Approximately half of the researchers surveyed view patents negatively, but have not experienced most of the professed negative effects in practice.

- Patents are shown to have fairly significant adverse impact on the dissemination of research information and knowledge.

- The data reveal a number of premises, that, while hardly significant, are worth exploring in future studies. Examples include the impact of patent access-blocking practices on innovation, and the utility of the information disclosure function of patents.

\section{Research commercialization is not perceived as a 'monster'}

- There was a low level of scepticism among researchers surveyed regarding the stem cell research commercialization agenda.

- Most researchers view commercialization positively, and the pressure to commercialize as reasonable.

- Researchers are involved in commercialization activities, and there is a high level of material and information sharing, mainly through material transfer agreements.

- The impact of commercialization on the training environment is viewed as positive or neutral.

\section{Bibliography}

Papers of special note have been highlighted as either of interest $(\bullet)$ or of considerableinterest $(\cdot \bullet)$ to readers.

1. Bouchard RA, Lemmens T:

Privatizing biomedical research: a 'third way'. N at. Biotechnol. 26(1), 31-36 (2008).

2. Vallas SP, Kleinman DL: Contradiction, convergence and the knowledge economy: the confluence of academic and commercial biotechnology. Socioecon. Rev. 6(2), 283-311 (2008).

3. Lemmens T: Leopards in the temple: restoring scientific integrity to the commercialized research scene. J. Law M ed. Ethics 32(4), 641-657 (2004).

- Discusses the implications of the commercialization of medical research, and reviews associated controversies.

4. Blumenthal D: Academic-industrial relationships in the life sciences. N. Engl. J. M ed. 349(25), 2452-2459 (2003).

5. Ehringhaus SH, Weissman JS, Sears JL, Goold SD, Feibelmann S, Campbell EG : Responses of medical schools to institutional conflicts of interest. JAM A 299(6), 665-671 (2008).

6. Rothman DJ: Academic medical centers and financial conflicts of interest. JAM A 299(6), 695-697 (2008).

7. Campbell EG, Clarridge BR, Gokhale M et al.: D ata withholding in academic genetics: evidence from a national survey. JAM A 287(4), 473-480 (2002).
8. Bekelman JE, Li Y, G ross CP: Scope and impact of financial conflicts of interest in biomedical research: a systematic review. JAM A 289(4), 454-465 (2003).

- Widely cited systematic review of original quantitative studies on the extent, impact and management of financial conflicts of interest in biomedical research.

9. Blumenthal D, Campbell EG, Gokhale M et al.: $\mathrm{D}$ ata withholding in genetics and the other life sciences: prevalences and predictors. Acad. M ed. 81(2), 137-145 (2006).

10. Hong W, Walsh JP: For M oney or Glory? Commercialization, competition and secrecy in the entrepreneurial university. Sociol. Q. (2008) (Epub ahead of print).

11. Friedman LS, Elihu D R: Relationship between conflicts of interest and research results. J. Gen. Int. M ed. 19(1), 51-56 (2004).

12. Caulfield $\mathrm{T}$ : The commercialization of medical and scientific reporting. PLOS M ed 1(3), 178-179 (2005).

13. Caulfield T, Einsiedel E, M erz J, N icol D: Trust, patents, and public perceptions: the governance of controversial biotechnology research. N at. Biotechnol. 24(11), 1352-1354 (2006).

- H ighlights the relevance of public perceptions and trust to sustainability of controversial biotechnology research, and identifies some useful mechanisms for promoting public trust in the research and associated outputs.
14. Critchley CR: Public opinion and trust in scientists: the role of the research context and the perceived motivation of stem cell researchers. Public U nderst. Sci. 17(3), 309-327 (2008).

15. Resnik D: Embryonic stem cell patents and human dignity. H ealth Care Anal. 15(3), 211-222 (2007).

16. Caulfield T: Stem cell patents and social controversy: a speculative view from Canada. M ed. Law Int. 7, 219-232 (2006).

17. Porter $G, D$ enning $C$, Plomer A, Sinden J Torremans $P$ : T he patentability of human embryonic stem cells in Europe. N at. Biotechnol. 24(6), 653-655 (2006).

18. Resnik $D:$ The commercialization of human stem cells: ethical and policy issues. H ealth Care Anal. 10(2), 127-154 (2002).

- Philosophical reflection on the arguments for and against commercialization and patenting policies as they relate to stem cells.

19. Rabino I: How human geneticists in US view commercialization of the $H$ uman Genome Project. N at. Genet. 29(1), 15-16 (2001).

20. Walsh JP, C ohen WM, Cho C: Where excludability matters: material versus intellectual property in academic biomedical research. Res. Policy 36(8), 1184-1203 (2007).

- Arguably seminal piece that examines the impact of patents on access to knowledge and materials used in subsequent research. Based on a survey of US biomedical researchers. 
21. Blumenthal $D, C$ ampbell EG, Anderson M S, Causino N, Louis KS: $W$ ithholding research results in academic life science. Evidence from a national survey of faculty. JAM A 277(15), 1224-1228 (1997).

- Study provides evidence of data withholding among biomedical researchers, and links this to research commercialization, among other causes.

22. Walsh JP, H ong W: Secrecy is increasing in step with competition. N ature 422 , 801-802 (2003)

23. O gbogu $U$ : The regulation of conflicts of interest in the $C$ anadian stem cell research environment. H ealth Law Rev. 16(2), 41-55 (2008).

- D irectly relevant to this paper. The author discusses the $C$ anadian stem cell research environment, and concerns about the growing focus on research commercialization.

24. H erder $\mathrm{M}$ : Proliferating patent problems with human embryonic stem cell research? J. Bioethical Inq. 3(1-2), 69-79 (2006).

25. Herder M, Brian JD: C anada's stem cell corporation: aggregate concerns and the question of public trust. J. Bus. Ethics 77(1), 73-84 (2008).

26. Caulfield T, O gbogu U, N elson E et al.: Stem cell research ethics: consensus statement on emerging issues. J. 0 bstet. Gynaecol. Can. 29(10), 843-848 (2007).

- Policy recommendations by international panel of stem cell scientists, law and public policy scholars, and policymakers on the normative response to emerging ethical, legal and social issues in stem cell research.

27. O gbogu U : A review of pressing ethical issues relevant to stem cell translational research. H ealth Law Rev. 14(3), 39-43 (2006).

28. Caulfield T, Cook-D eegan RM, Kieff FS, Walsh JP: Evidence and anecdotes: an analysis of human gene patenting controversies. Nat. Biotechnol. 24, 1091-1094 (2006).
- The authors question the evidence used to support gene patent policies, concluding that policymakers might be reacting more to high-profile patent controversies rather than actual systematic data.

29. Caulfield T: An independent voice? Conflicts of interest and research on ethical, legal and social issues. H ealth Law Rev. 13(2,3), 114-116 (2005).

30. N elson E, O gbogu U, Caulfield T: An investigation of embryo donation, informed consent and research oversight in Canadian human embryonic stem cell research. J. O bstet. Gynaecol. Can. 29(12), 997-1002 (2007).

31. Kitch $E W$ : The nature and function of the patent system. J. Law Econ. 20(2), 265-290 (1977).

32. M azzoleni $R, N$ elson RR: The benefits and costs of strong patent protection: a contribution to the current debate. Res. Policy 27(3), 273-284 (1998).

33. Caulfield $T$ : Sustainability and the balancing of the health care and innovation agendas: The commercialization of genetic research. Sask. Law Rev. 66(2), 629-645 (2003).

- D iscussion of the conflicts in the combined pursuit of innovation and commercialization agendas in contemporary biomedical research.

34. American Association for the Advancement of Science: International Intellectual Property Experiences: A Report of Four Countries Project on Science and Intellectual Property in the Public Interest. Washington, DC, USA: Directorate for Science and Policy Programs, American Association for the Advancement of Science (2007).

35. H arvard College vs $\mathrm{C}$ anada (C ommissioner of Patents), SCC 76, 4 S.C.R. 45 (2002).

36. Check $\mathrm{E}: \mathrm{C}$ anada stops $\mathrm{H}$ arvard's oncomouse in its tracks. $\mathrm{N}$ ature 420, 593 (2002).
37. M akin $\mathrm{K}$, Yourk D: $\mathrm{H}$ arvard mouse can't be patented. The Globe and M ail, Technology section, front page. D ecember 5 (2002).

38. Scassa T: A mouse is a mouse is a mouse: a comment on the supreme court of $\mathrm{C}$ anada's decision on the $\mathrm{H}$ arvard mouse patent ( $\mathrm{H}$ arvard College vs $\mathrm{C}$ anada ( $\mathrm{Comr}$ of Patents). 0 xford U niv. Commonwealth Law J. 3, 105-117 (2003).

39. Caulfield T: Policy conflicts: gene patents and health care in $C$ anada. Community Genet. 8(4), 223-227 (2005).

40. Thomas S: Their hands on your genes. N ew Sci. 175(2354), 25 (2002).

41. Gold RE: From theory to practice: health care and the patent system. H ealth Law J. (Special Edition) 21-40 (2003).

42. Vogeli $C$, Yucel R, Bendavid $E$ et al.: $D$ ata withholding and the next generation of scientists: results of a national survey. Acad. M ed. 81(2), 128-136 (2006).

Websites

101. Plomer A: Stem cell patents: European patent law and ethics report. The U niversity of N ottingham, 28 July (2006). www.nottingham.ac.uk/law/StemC ell Project/project.report.pdf

102. Canadian federal government's $N$ etworks of C entres of Excellence program. www.nce.gc.cal

103. Walsh J, Cho C, Cohen W: Patents, material transfers and access to research inputs in biomedical research: final report to the national academy of science's committee intellectual property rights in genomic and protein-related inventions (2005). http://tigger.uic.edu/jwalsh/N ASR eport. html

104. Gorman C: A mouse that roared. Time (1988). www.time.com/time/magazine/article/ 0,9171,967208,00.html 


\section{Appendix}

- TableA1. Breakdown of sample group and survey administration.

- FigureAl I mpact of patents on the research environment.

- FigureA2. Impact of patents on knowledge dissemination practices.

- FigureA3. Patent licensing practices: refusal to licence.

- FigureA4. Patent licensing practices: denial of requests for licence.

- FigureA5. Sharing of research materials.

- FigureA6. Refusal to share research materials.

- FigureA7. Impact of commercialization agenda on research.

- FigureA8. Impact of commercialization agenda on teaching and training activities.

- FigureA9. Sources of commercialization pressure.

\section{Table A1. Breakdow $\mathbf{n}$ of sample group and survey administration.}

\begin{tabular}{|c|c|}
\hline Total number of scientific investigators in the Network & 62 \\
\hline $\begin{array}{l}\text { Number of scientific investigators active in Network at the } \\
\text { time of survey }\end{array}$ & 47 \\
\hline $\begin{array}{l}\text { Scientific investigators in attendance at AGM and } \\
\text { participating in survey }\end{array}$ & 42 (includes 31 active and 11 inactive investigators) \\
\hline Total number of Network trainees & 367 \\
\hline Trainees in attendance at AGM and participating in survey & 204 \\
\hline Number of surveys distributed & 283 \\
\hline Number of surveys returned & 108 \\
\hline $\begin{array}{l}\text { Number of respondent investigators included in } \\
\text { final sample }\end{array}$ & $\begin{array}{l}27 \text { (approximately } 64 \% \text { of scientific investigators participating in survey, } \\
\text { and } 44 \% \text { of Network scientific investigators) }\end{array}$ \\
\hline Number of trainees included in final sample & 81 (approximately $40 \%$ of trainees participating in survey) \\
\hline
\end{tabular}

\section{Figure A1. Impact of patents on the research environment.}

Overall, in the context of stem cell research, do you feel that patents have negative, positive or neutral impact on the research environment?

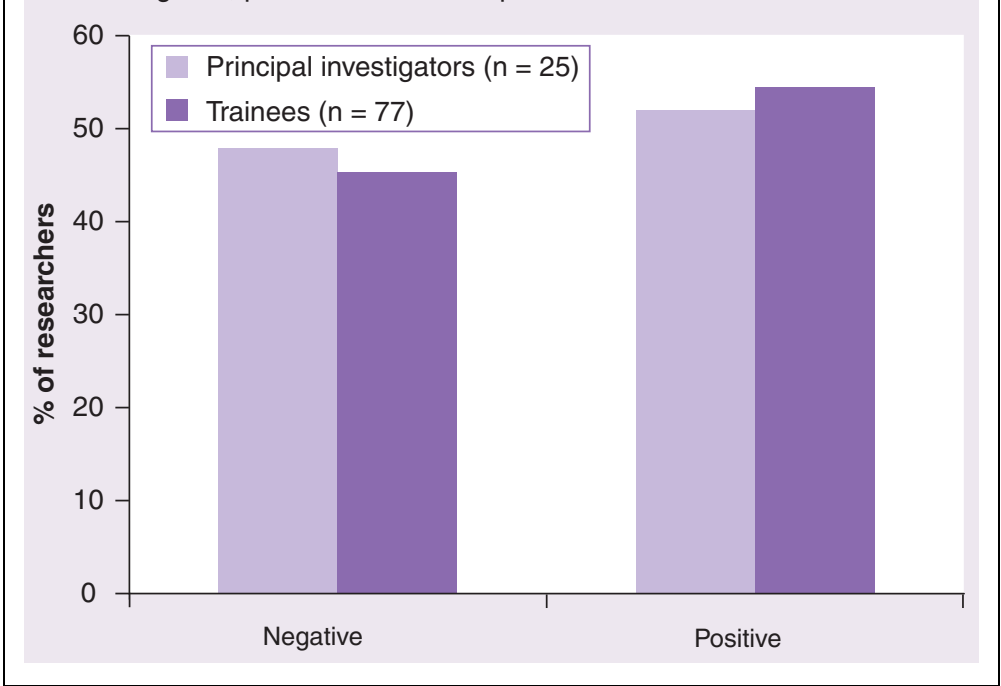


Figure A2. Impact of patents on knowledge dissemination practices.

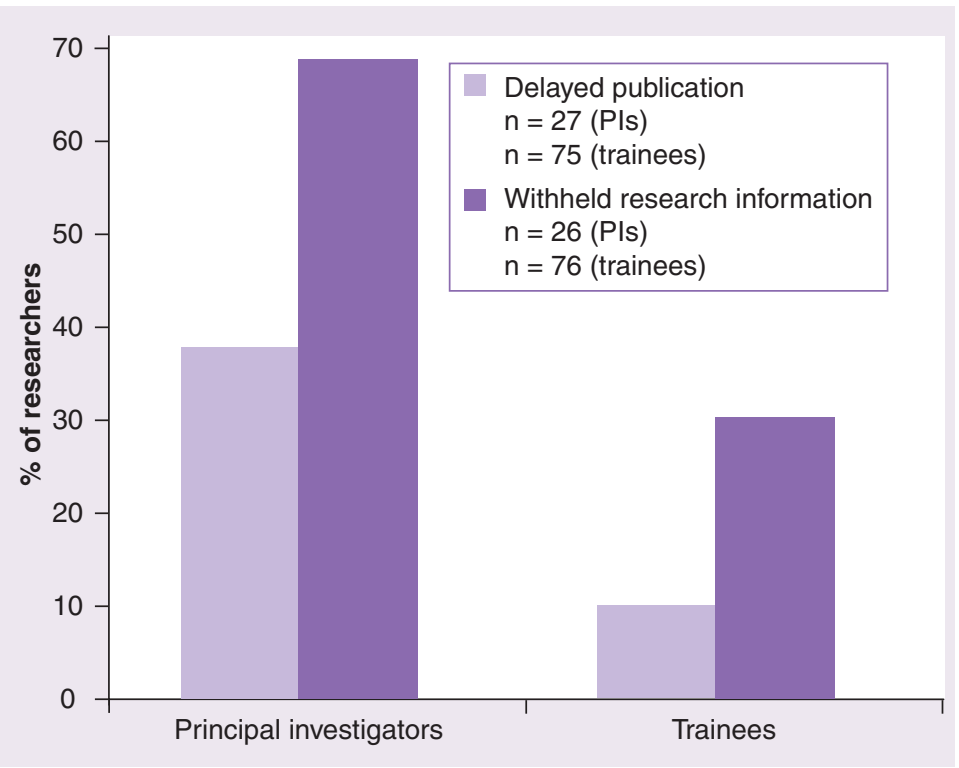

Percentage of researchers who delayed publication or withheld information to protect potential patents.

PI: Principal investigator.

\section{Figure A3. Patent licensing practices: refusal to licence.}

Have you ever refused to license your patented technology to someone who has approached you with a request for a licence?

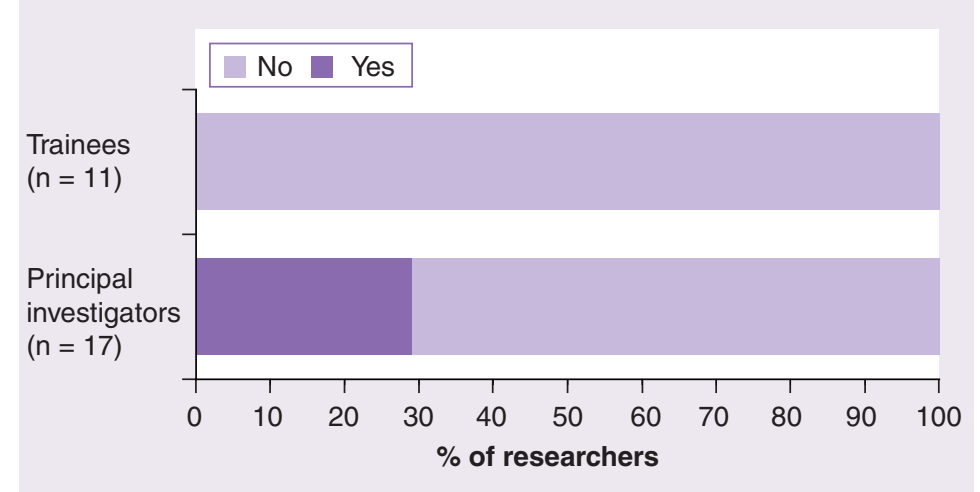




\section{Figure A4. Patent licensing practices: denial of requests for a licence.}

Have you ever been refused a licence to a patented technology that you needed for your research?

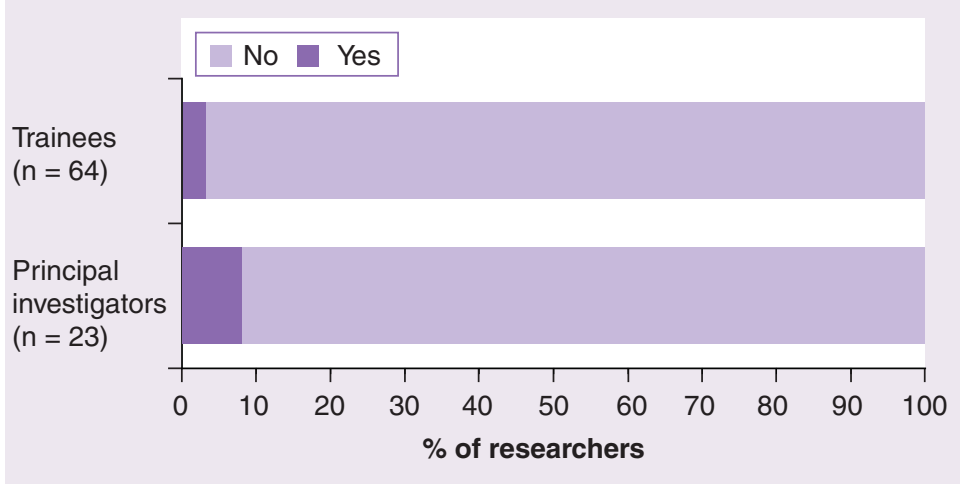

\section{Figure A5. Sharing of research materials.}

Do you routinely share research materials with colleagues at other institutions or within private firms?

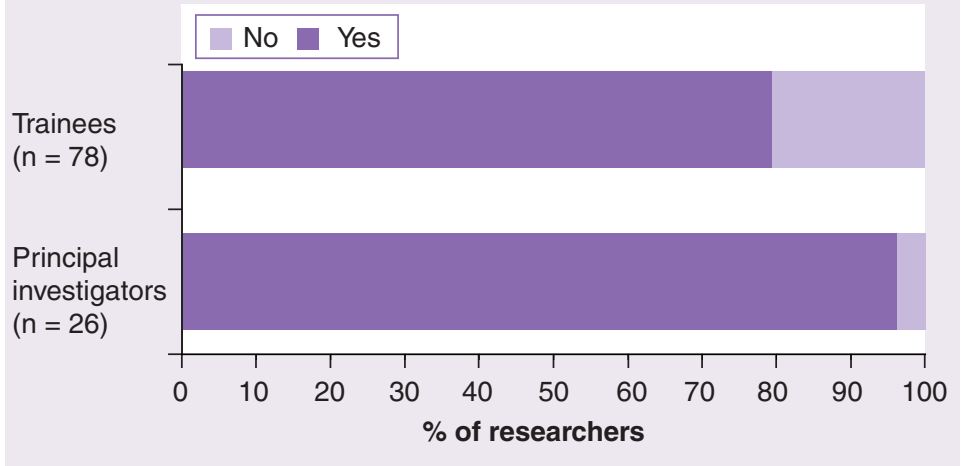

\section{Figure A6. Refusal to share research materials.}

Have you ever refused to provide research materials to a requesting party?

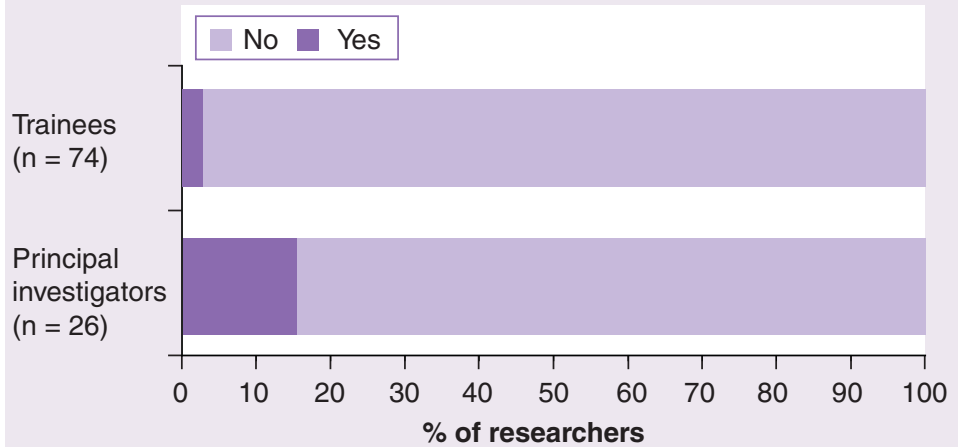




\section{Figure A7. Impact of commercialization agenda on research.}

Overall, do you feel that the Stem Cell Network's position on commercialization has a positive, negative or neutral impact on your research efforts?

$$
\text { Neutral Negative } \square \text { Positive }
$$

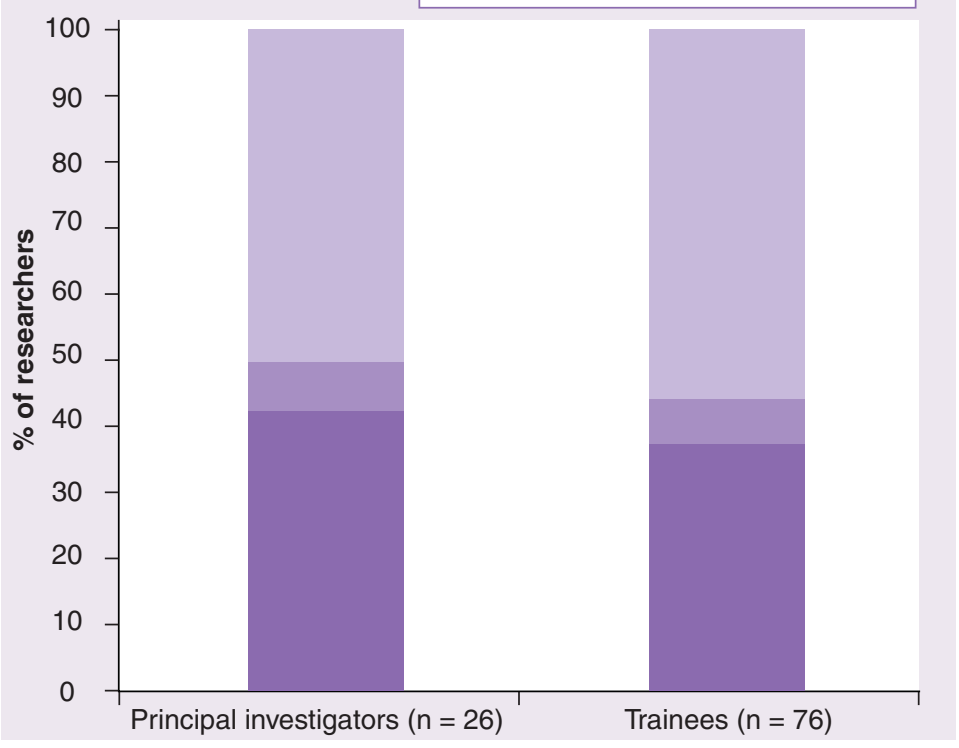

\section{Figure A8. Impact of commercialization agenda on} teaching and training activities.

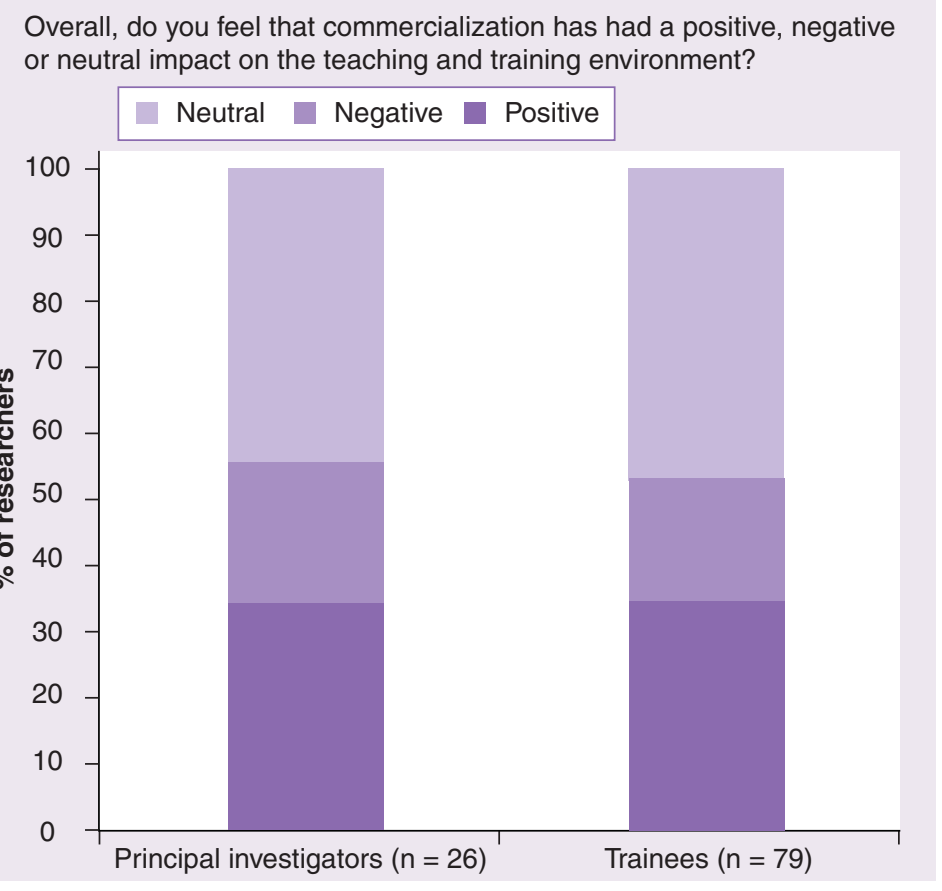




\section{Figure A9. Sources of commercialization pressure.}

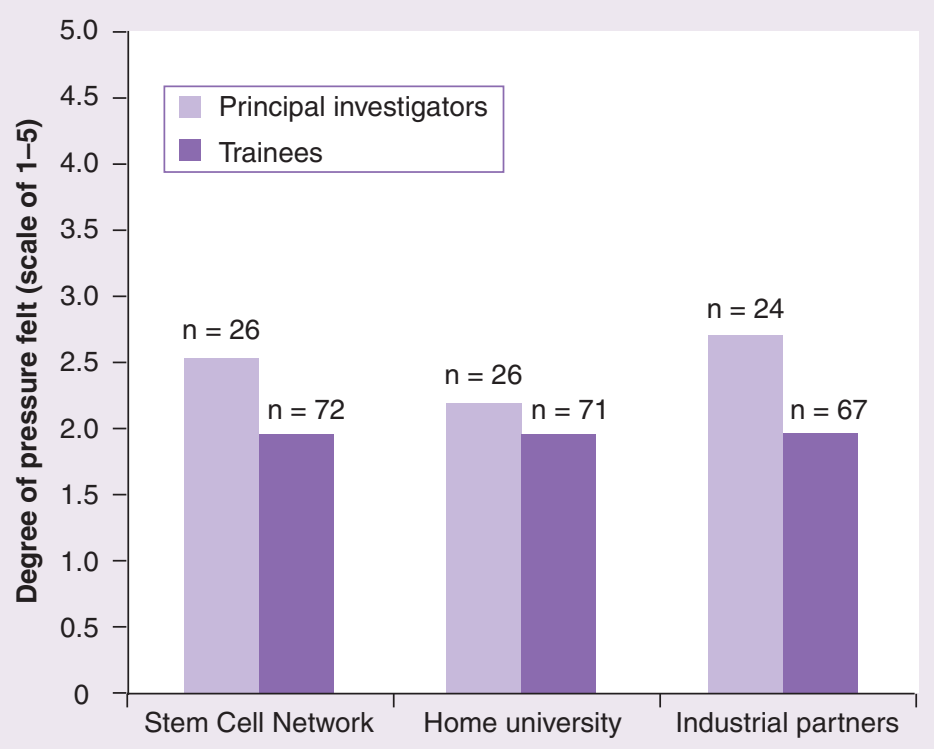

Degrees of commercialization pressure felt from different sources. 